\title{
Analysis of Land Use and Land Cover Changes in the Wetland Ecosystem of Port-Harcourt Metropolis, Nigeria
}

\author{
Wali Elekwachi ${ }^{1}$, Phil-Eze P. O. ${ }^{1}$, Nwankwoala Hycienth O. ${ }^{2}$, Bosco-Abiahu Lilian. C. ${ }^{3}$ \& Emelu Victoria O. ${ }^{4}$ \\ ${ }^{1}$ Department of Geography, University of Nigeria, Nsukka, Nigeria \\ ${ }^{2}$ Department of Geology, University of Port Harcourt, Nigeria \\ ${ }^{3}$ Department of Environmental Technology, Federal University of Technology Owerri, Nigeria \\ ${ }^{4}$ Center for Disasters Risk Management and Development Studies, University of Port-Harcourt, Nigeria \\ Correspondence: Wali Elekwachi, Department of Geography, University of Nigeria, Nsukka, Nigeria.
}

Received: July 18, 2019 Accepted: October 18, 2019 Online Published: October 20, 2019

doi:10.5539/emr.v8n2p54 URL: https://doi.org/10.5539/emr.v8n2p54

\begin{abstract}
The study analyzed changes in land use and land cover overtime in Port-Harcourt metropolis using remote sensing techniques from 1984-2013.The Geo-referencing properties of 1984, 1999, 2003 and 2013 include; universal Transverse Mercator (UTM) projection, and datum WGS 84, zone 32, ERDAS Imagine (2014).These were used for displaying processing, enhancement, classification of the imageries and also used for the delineation of the study area imagery. IDRIS SELVA was used for the development of land use land cover classes. ArcGIS 10.1was used in developing, display and processing of the location maps. Total percentage change and total rate of change for the entire trend after conversion are thus: Saltwater Wetland 23.44\%, to- 2.17, Freshwater Wetland - 26.44\%to- 11.49 Fallow land- 47.13\%to- 5.41 Built-up Area 43.33\% to 7.41Water bodies $43.36 \%$ to 3.06 . The study recommended that activities shrinking wetlands size should be thoroughly put to check by the government and better efforts should be focused on those activities that inspire wetland conservation.
\end{abstract}

Keywords: land use /land cover, wetlands, ecosystem, remote sensing, GIS, Ramsar

\section{Introduction}

Wetland variation appraisal is a component that covers land use change overtime. This requires an in -depth analysis in terms of the spatial coverage at a given time (Fonji \& Taff, 2014). Land use/ land cover change is one of the major challenges that impacts on the natural landscape. It is also the primary driving force of global environmental change, and significant to sustainable development debate (Lambin et al., 2000). Causes and consequences of land use change at the physical and social surroundings have been an area for research over a decade (Veldkamp \& Verburg, 2004; Victor et al., 2011). These consist of its effect on wetland/water quality, land and air resources, surroundings, ecosystem processes and function, and weather change (Lambin et al., 2000); biodiversity (Liu \& Ashton, 1998), soil degradation (Trimble \& Crosson, 2000) and the potential of natural systems to support existence (Vitousek et al., 1997).

Port-Harcourt city is situated in wetland ecosystem. As a result of increase in population explosion, urban migration and failure of successive governments to manage urban growth, the metropolis has expanded in an unplanned way which has led to acquisition of more lands in the wetland vicinity (Wali et al., 2018a; Wali et al., 2018b). Port Harcourt wetland has suffered major important encroachment in the recent past. A visit to the wetland shows ample of new activities, which depict massive encroachment. The activities encompass; residential and industrial buildings, exploration and exploitation, of natural resources among others (Wali, 2015; Wali et al., 2018a; Wali et al., 2018b).

Some of the contemporary studies to identify, display or monitor wetlands and their modifications with remote sensing and GIS, involve the study of saltwater-freshwater wetland ecosystem and urban land use change in Port-Harcourt metropolis (Wali et al., 2018a); Forecasting the future pattern of land use and land cover change in the wetland ecosystem of the Port Harcourt metropolis (Wali et al., 2018b; Eludoyin et al., 2015); studied spatio -temporal analysis of wetlands modifications in Port -Harcourt metropolis, using geo-information techniques from 1984-2015; (Wali, 2015); studied urbanization and loss of wetlands in Port Harcourt metropolis using 
remote- sensing techniques;(Mmom et al., 2013); examined the land use and land cover changes in Port Harcourt metropolis and its environ using GIS and remote sensing techniques; (James et al., 2007); monitoring of land degradation along Ondo coastal zone of Nigeria (Abbas, 2008); the monitoring of wetlands in the semi-arid west, USA (Neale et al., 2007); The mapping of Canada's wetland with optical, radar and DEM data (Li \& Chen, 2005); the inventory monitoring of temporary and permanent wetlands of western cape, South Africa (De- Roeck et al., 2008) and the spatial-temporal analysis of wetland losses in the Lagos coastal zone (Taiwo \& Areola, 2009). Tijani et al. (2011) in their study of Eleyele wetland in Ibadan through GIS based fully assessment revealed a reduction in the riparian wetland forest $1.25 \mathrm{~km}^{2}$ as at 1984 to $0.70 \mathrm{~km}^{2}$ by 2004 with a projected decline of $0.42 \mathrm{~km}^{2}$ by 2014. One could infer from the different empirical studies as emphasized above, that there is an immense negative impact of human induced influence on the wetland ecosystem through urban development activities, therefore, depriving human and aquatic lives the benefits of wetlands. However, most of these studies made use of Geo-Information techniques in their analysis, but just few studies explored land use and land cover change. It is against this background, this study analyzed land use and land cover change in the wetland ecosystem of Port - Harcourt metropolis, Nigeria.

\section{Materials and Methods}

\subsection{Study Area Description}

Geographically, the Port-Harcourt metropolis features between Latitudes $4^{\circ} 45^{\prime} \mathrm{N}$, and $4^{\circ} 55^{\prime} \mathrm{N}$ and Longitudes $6^{\circ} 55^{\prime} \mathrm{E}$ and $7^{\circ} 05^{\prime} \mathrm{E}$. Port-Harcourt metropolis is sited at about $25 \mathrm{~km}$ from the Atlantic Ocean and it is located between the Dockyard Creek/Bonny River and the Amadi Creek (Okoye, 1975; Oyegun et al., 1999). Port-Harcourt, formerly known, as "Igwe-Ocha" was established in 1913 by the British in an area traditionally inhabited by the Ikwerre. It was christened after Lewis Viscount Harcourt, the then Secretary of State of Colonies. The key City of Port Harcourt is the Port-Harcourt City Local Government Area. It serves as the administrative Headquarters of Rivers State (Alagoa et al., 2002). Currently, the Port-Harcourt metropolis is made up of two Local Government Areas, namely Port-Harcourt L.G.A and Obio-Akpor LGA.

The surface area of land is low-lying and the rivers are swayed by tidal oscillation. Port-Harcourt metropolis lies at an average elevation of about $12 \mathrm{~m}$ above mean sea level. In expressions of general surface features, the Port-Harcourt metropolis is very unique. The area falls within the coastal belt conquered by Low-Lying coastal plains which structurally belong to the sedimentary formation of the recent Niger Delta (Umeuduji \& Aisuebeogun, 1999). It contains mainly of muddy deposit pushed out of the River Niger into a comparatively tide-less salt sea. The Port-Harcourt metropolis is drained by many rivers such as, Ntawogba, New Calaba, Amadi creek, Dockyard creek, Dick Fiberesima creek, Isaka River, Mini Apalugo, Elechi creek, Primose River, Mgbuodohia River, etc. Izeogu and Aisuebeogun (1989) viewed the beach ridge barrier islands as depositional land forms which receive fine coarse grained sands from the sea with height of just about $13 \mathrm{~m}$ above sea level. Chiadikobi et al. (2011) in their empirical studies observed that most rivers and creeks in Port Harcourt and its environs shows that the network pattern created does not easily fit the convectional, typical dendritic and trellised pattern of drainage. The entire area is crisscrossed by numerous rivers and creeks which empty into the Atlantic Ocean.

The inhabitants of Port-Harcourt city (within its metropolitan borders) has grown from 7,000 dwellers in 1921 to more than 538,558 in 2006. According to the 1963 National population poll outcomes, Port-Harcourt had a population of 179,563 persons (Ogionwo, 1979). With rise in the number of residents, the 1991 National population poll outcomes showed that Port-Harcourt and Obio-Akpor LGAs had a population of 703,416 persons (Akpoghomeh, 2001). Though, in 2006, the population of the Port Harcourt Metropolis grew to 1, 000, 908 persons (National population Commission, 2006) with Obio-Akpor LGA having 462,350 persons while Port Harcourt LGA had 538,558 persons (NPC, 2006). This present statistics of the two Local Government Areas gave the aggregate population density of the study area to be 2695per square kilometers.

Built-up for land use and other activities, have put stress on wetland in the study area. Growth of town and city has infringes towards wetland due to high population density and the appropriateness of the areas for infrastructural development has increased stress to the wetland in the study area. For example, the inhabitants of the Port-Harcourt metropolis have increased rapidly over the years. As a result of population growth, areas that were known as wetlands (See Figures 1-8) have been transformed into built-up areas and other infrastructures.

During the field survey, a reconnaissance survey has been carried out to enable the researcher familiarize with the study area (Appendix 1). Global Positioning System (GPS) was used to determine the locations of various Land use/land cover in Port Harcourt metropolis. Throughout the field survey, coordinates of various land use/land cover in the study area have been ascertained and validated in order to improve the accuracy of the area 
in question. Coordinates of the classification types were computed in $\mathrm{X}$ and $\mathrm{Y}$ coordinate data set in ArcGIS 10.1 environment for decimal of degrees. i.e, Decimal of Degree $=$ Degree $+(($ Minutes/ 60$)+($ Seconds/3600 $))$.
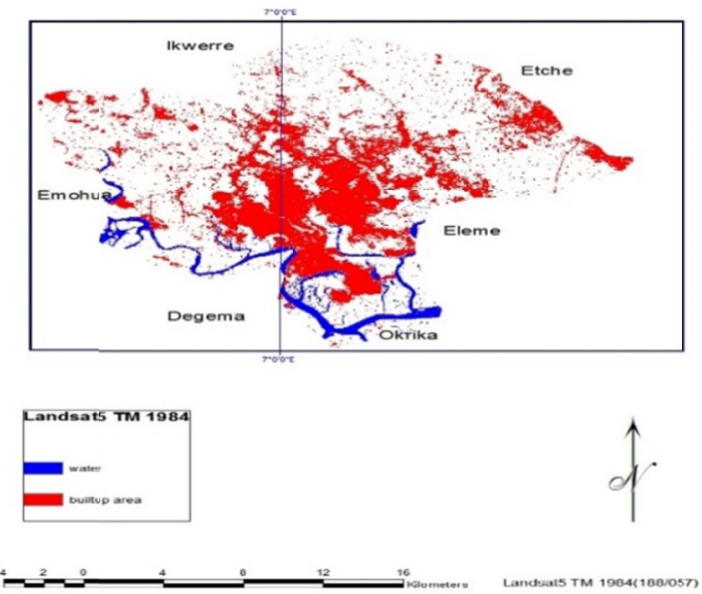

Figure 1. Spatial Extent of Built-up Area of Port Harcourt Metropolis in 1984
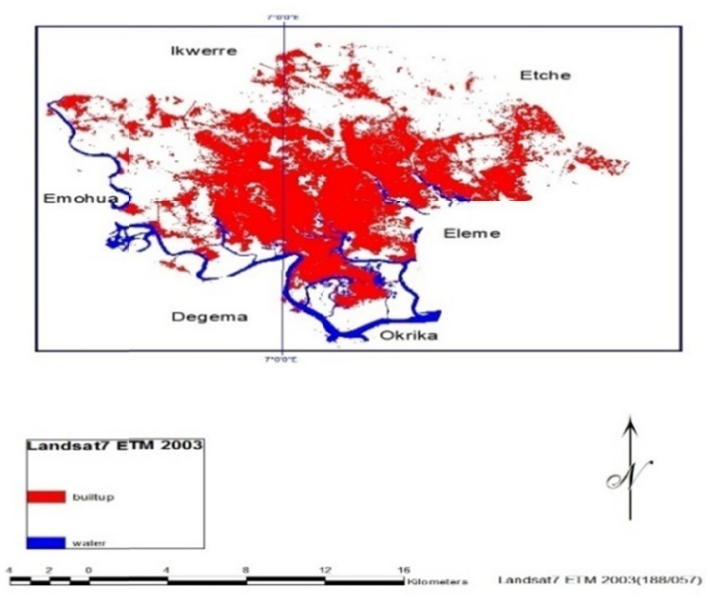

Figure 3. Spatial Extent of Built-up Area of Port Harcourt Metropolis in 2003

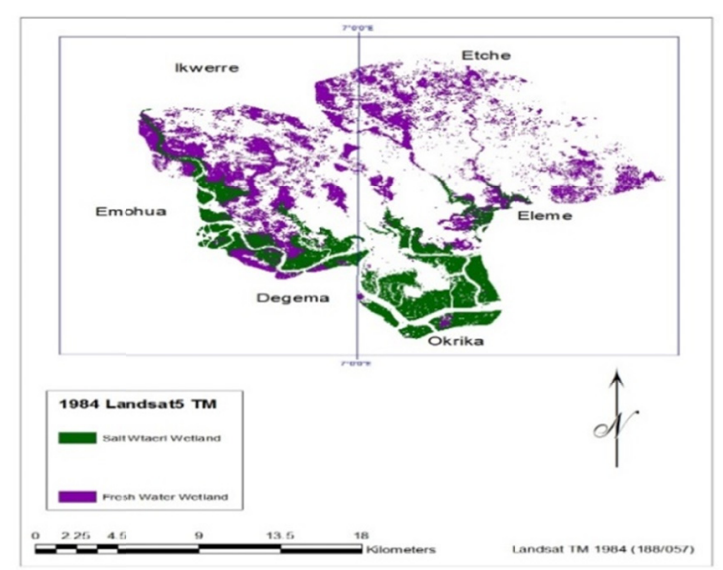

Figure 5. Spatial Extent of Saltwater and Freshwater Wetlands of Port Harcourt Metropolis in 1984
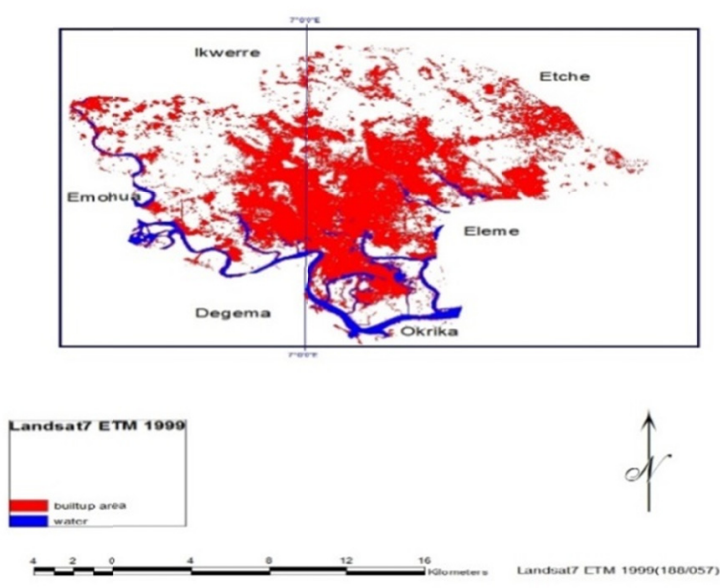

Figure 2. Spatial Extent of Built-up Area of Port Harcourt Harcourt Metropolis in 1999
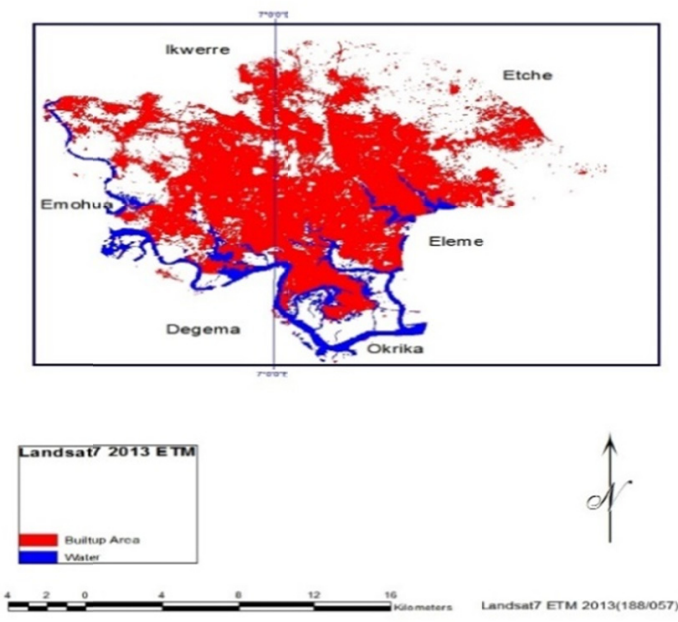

Figure 4. Spatial Extent of Built-up Area of Port Harcourt Metropolis in 2013

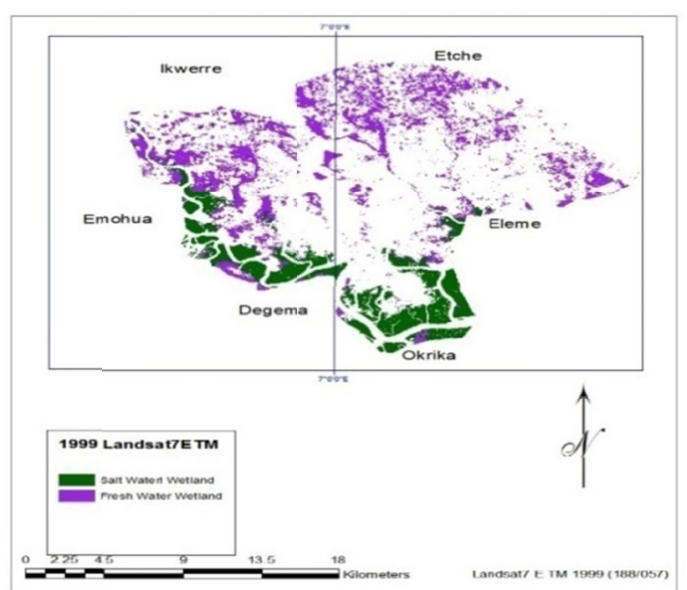

Figure 6. Spatial Extent of Saltwater and Fresh- water Wetland of Port Harcourt Metropolis in 1999 


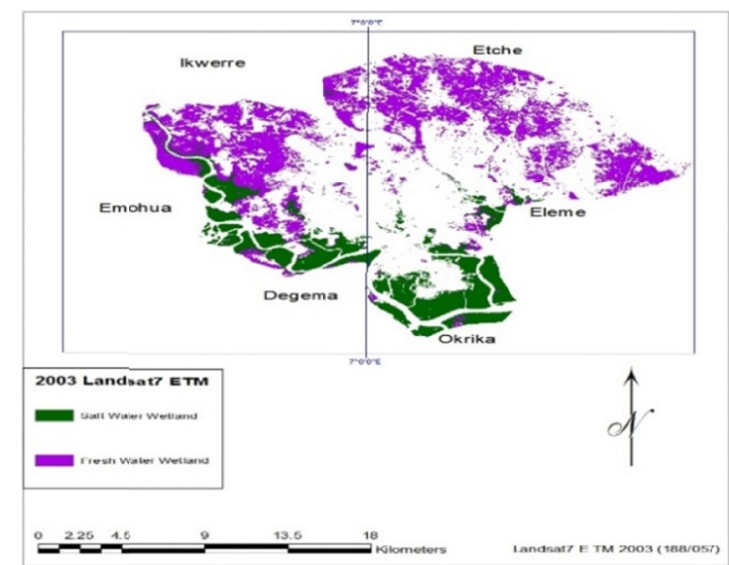

Figure 7. Spatial Extent of Saltwater and Freshwater Wetlands of Port Harcourt Metropolis in 2003

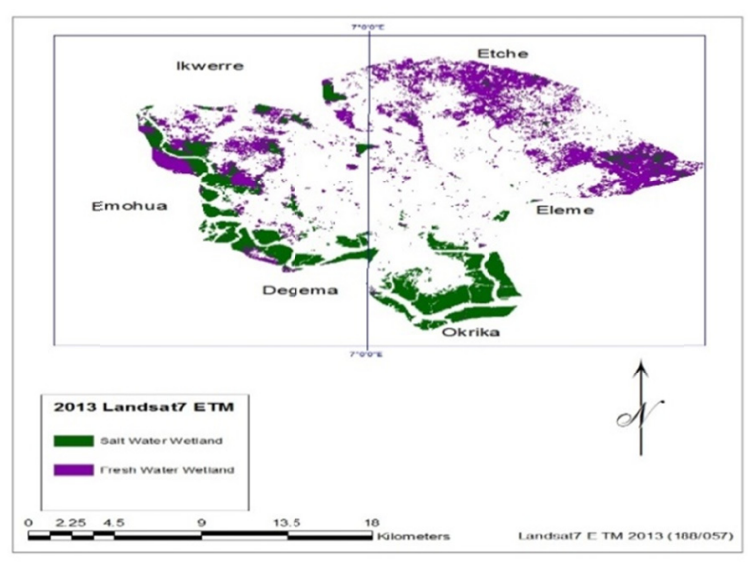

Figure 8. Spatial Extent of Saltwater and freshwater Wetlands of Port Harcourt Metropolis in 2013

\subsection{Image Geo -referencing and Wetland Mapping}

The Geo-referencing properties of 1984, 1999, 2003 and 2013 made up of Universal Transverse Mercator (UTM) projection, and datum WGS 84, zone 32, ERDAS Imagine (2014) were used for displaying processing, enhancement, classification of the imageries and also used for the delineation of the study area imagery( See Figures 9-12). IDRIS SELVA was used for the development of land use land cover classes for the study area. ArcGIS 10.1 was used in developing, display and processing of the location maps. The spectral resolution of Landsat TM and ETM+ $(30 \mathrm{~m})$ data makes it very useful for land use change and land cover classification and overall mapping. The categorized land use images were later converted to vector format to compute the area of land use which in each year in hectares using spatial query module in ArcGIS 10.1. The wetlands were detached from other land use to create a spatial distribution map of wetlands and simple arithmetic was used to determine the area, trend, direction and percentage of change of wetlands in Port Harcourt Metropolis. The percentage of wetland lost to other land use was also computed in ArcGIS 10.1.Also the rate of land use and land cover changes for the for a successive periods 1984-1999 and 2003-2013 as shown in table 3 was calculated using the following formula:

Change $=$ Current Year - the Previous Year

$$
\begin{aligned}
& \% \text { change }=\frac{\text { current Year-Previous Year }}{\text { Previours }} \times \frac{100}{1}=\text { Trend } \\
& \text { Annual Rate of Change }=\frac{\% \text { change } \times \text { the number of years }}{100}
\end{aligned}
$$




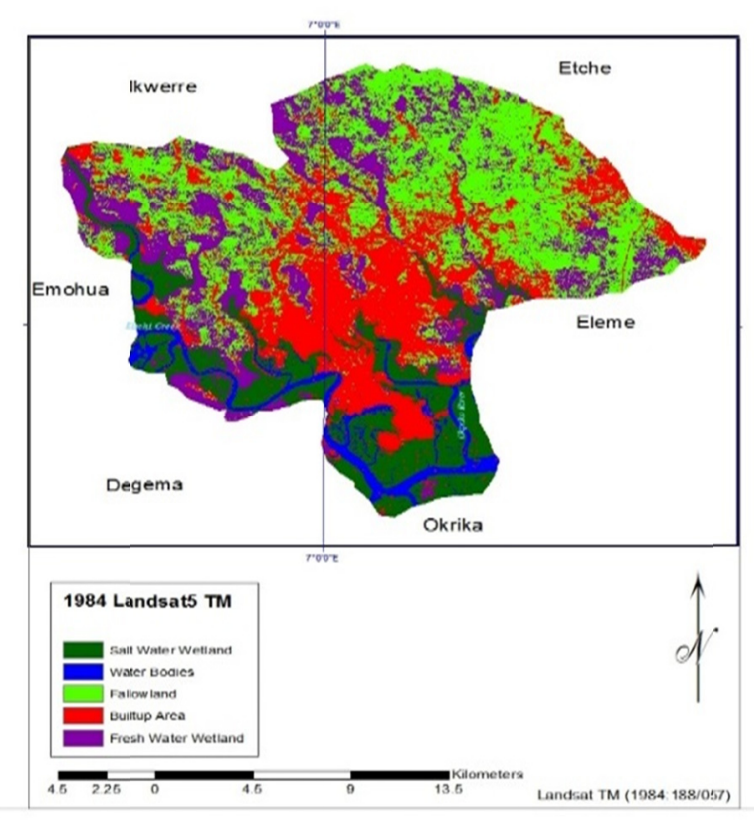

Figure 9. Land use/Land cover pattern of Port Harcourt Metropolis in 1984

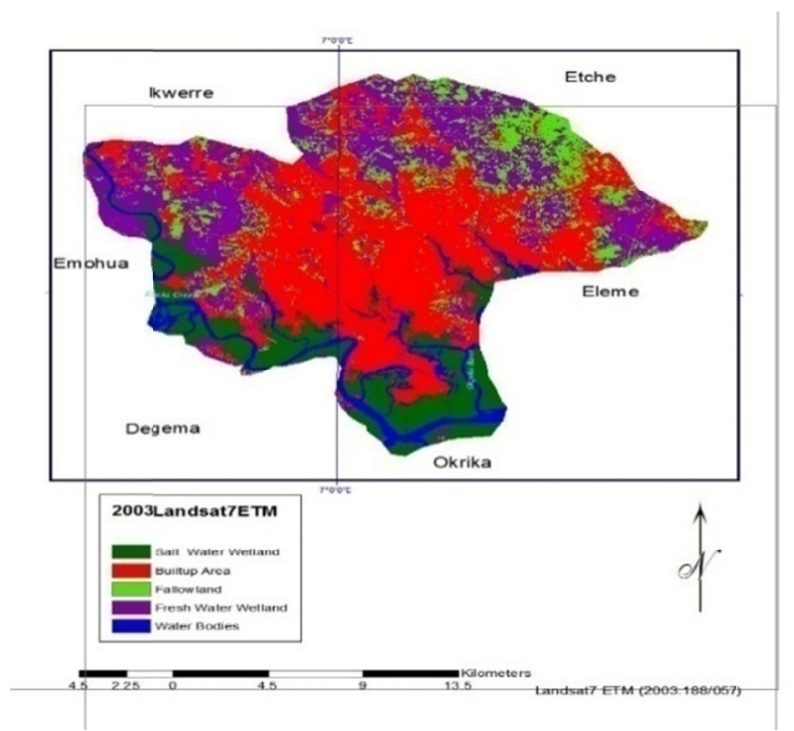

Figure 11. Land use/Land cover pattern of Port Harcourt Metropolis in 2003

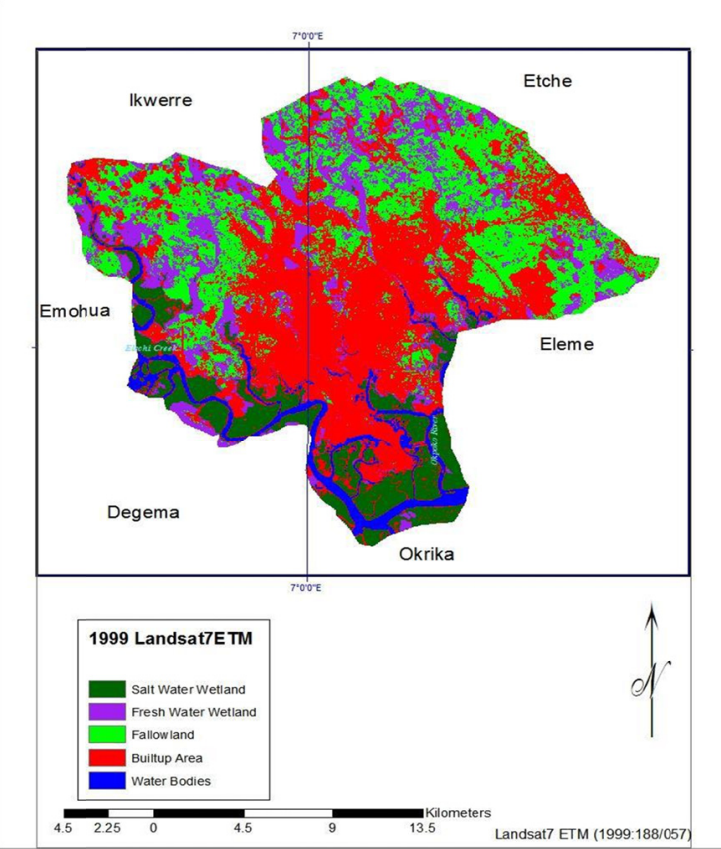

Figure 10. Land use /Land cover pattern of Port Harcourt Metropolis in 1999

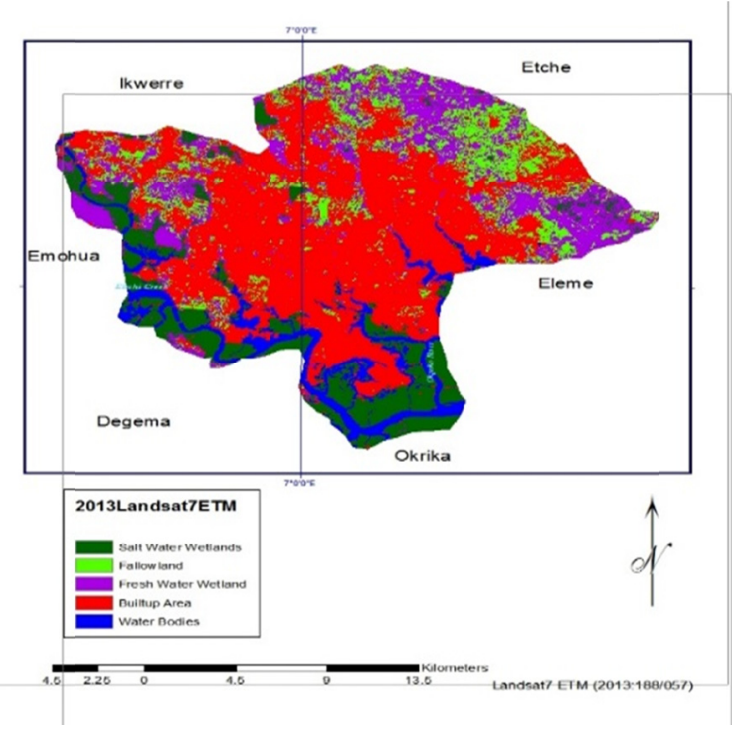

Figure 12. Land use/cover pattern for 2013

Table 1. Landsat satellite images characteristics

\begin{tabular}{|c|c|c|c|c|c|c|c|c|}
\hline $\mathrm{S} / \mathrm{N}$ & $\begin{array}{l}\text { SATELITE/ } \\
\text { DATA } \\
\text { TYPE }\end{array}$ & SENSOR & PATH/ROW & DATE & SACLE/RESOLUTIONS & BANDS & $\begin{array}{l}\text { CLOUD } \\
\text { COVER }\end{array}$ & SOURCE \\
\hline 1 & Landsat 5 & $\begin{array}{l}\text { Thematic } \\
\text { Mapper (TM) }\end{array}$ & $188 / 057$ & $13 / 12 / 84$ & $30 \mathrm{~m} \times 30 \mathrm{~m}$ & $\begin{array}{l}1,2,3,4,5,6 \\
\text { and } 7\end{array}$ & 0 & $\begin{array}{l}\text { Courtesy of } \\
\text { the U.S. } \\
\text { Geological } \\
\text { Survey. Earth }\end{array}$ \\
\hline
\end{tabular}




\begin{tabular}{|c|c|c|c|c|c|c|c|c|}
\hline & & & & & & & & Explorer. \\
\hline 2 & Landsat 7 & $\begin{array}{l}\text { Enhanced } \\
\text { Thematic } \\
\text { Mapper plus } \\
(\text { ETM+) }\end{array}$ & $188 / 057$ & 29/11/1999 & $30 \mathrm{~m} \times 30 \mathrm{~m}$ & $\begin{array}{l}1,2,3,4,5,6 \\
\text { and } 7\end{array}$ & $10 \%$ & $\begin{array}{l}\text { Courtesy of } \\
\text { the U.S. } \\
\text { Geological } \\
\text { Survey. Earth } \\
\text { Explorer. }\end{array}$ \\
\hline 3 & Land sat7 & $\begin{array}{l}\text { Enhanced } \\
\text { Thematic } \\
\text { Mapper plus } \\
(\text { ETM+) }\end{array}$ & $188 / 057$ & $08 / 01 / 2003$ & $30 \mathrm{~m} \times 30 \mathrm{~m}$ & $\begin{array}{l}1,2,3,4,5,6 \\
\text { and } 7\end{array}$ & 0 & $\begin{array}{l}\text { Courtesy of } \\
\text { the U.S. } \\
\text { Geological } \\
\text { Survey. Earth } \\
\text { Explorer. }\end{array}$ \\
\hline 4 & Land Sat7 & $\begin{array}{l}\text { Enhanced } \\
\text { thematic } \\
\text { Mapper plus } \\
(\text { ETM+) }\end{array}$ & $188 / 057$ & $21 / 12 / 2013$ & $30 \mathrm{~m} \times 30 \mathrm{~m}$ & $\begin{array}{l}1,2,3,4,5,6 \\
\text { and } 7\end{array}$ & 0 & $\begin{array}{l}\text { Courtesy of } \\
\text { the U.S. } \\
\text { Geological } \\
\text { Survey. Earth } \\
\text { Explorer. }\end{array}$ \\
\hline
\end{tabular}

(Source: U.S Geological Survey, 2014)

\subsection{Land use Class Inventory}

The classification scheme obviously displays the details of the land use/land cover types used in defining the various categories of land use and land cover types in the study area. In this research Anderson et al., (2001) classification scheme was adopted, and Table 2 shows this class.

Table 2. Land use /land cover classification scheme: adapted from Anderson et al. (2001)

\begin{tabular}{lll}
\hline S/N & LEVEL 1 & LEVEL II \\
\hline 1 & SALTWATER WETLAND & Beach/tidal and sub tidal land of Salt water ecosystems \\
2 & FRESHWATER WETLAND & Swamps, marshes, fresh water eco- system \\
3 & FALLOW LAND & Farmland, sparse vegetation and thick vegetation. \\
4 & BUILT-UP AREA & $\begin{array}{l}\text { Urban, industrial , bare soil residential, commercial, road } \\
\text { educational, rail-way line and pipeline etc. }\end{array}$ \\
5 & WATER BODIES & $\begin{array}{l}\text { Exposed water bodies within the study area including river, } \\
\text { stream, lake and rivulet and creeks }\end{array}$ \\
\hline
\end{tabular}

Saltwater Wetland: These wetland consist of all tidal and sub-tidal lands, including all areas below any recognizable debris left by tidal action. It is mainly salt water ecosystem.

Freshwater Wetland: These consist of an area or a portion of land cover with water with ferns, shrub and short mangrove with marshy land.

Fallow: These are areas covered with fallow land and agricultural land, of high or low impact on human activities. These areas are associated with wetlands but some distance away from the water courses.

Built-Up Area: These are areas under intensive use with most of the land covered with structures that are under these classes such as: industrials, bare soil, commercial, educational, settlement, villages, infrastructures, road network, oil and gas facilities - pipelines, flow lines, manifold, well heads, gas plant, flow station, rail way / mono-rail, filling stations, hospital, churches, mosque, military barracks, open and closed areas.

Water Bodies: These are areas covered mostly with exposed body of water such as creeks, rivulets, ponds, rivers of various tributaries and seas that flow in the study area.

Wetlands identified throughout the study show a lot of activities that took place that are still taking place in the wetlands of the study area. Land use activities such as infrastructural development, sewage and solid waste disposal and settlement have been and continue to be undertaken in the wetlands of the study area. 


\section{Results and Discussions}

\subsection{Wetlands and Other Land Use and Land Cover Change Analyses}

Table 3 Provides information on the overall land use and land cover change from 1984-1999, 1999-2003 and 2003-2013 based on the land use and land cover maps as shown in figures 5-8. Both the absolute percentage increments between the two years and relative percentage increment from 2003 were also calculated. Negative symbols in the statistics indicated a loss in the class (SER) IUCN (2006) Oludare et al. (2015).

The results revealed that urban development change is very low in the study area from - 14.73\% (-896.29 Ha) of the total land 1984-1999 with an annual rate of change of -2.21 of saltwater wetland, fallow land $-2779.34 \%$ with an annual rate of change of -5.36 . Analysis shows that water bodies fall within $-4.81(-112.99 \mathrm{Ha})$ and annual rate of -0.72 respectively which signifies the fluctuating ratio of the water cover in the study area. These low changes translated into increase in the amount of other class. Within this period there was an exponential positive growth in freshwater wetland with a change in $135.62 \mathrm{Ha}$ with a percentage change of $1.06 \%$ and an annual rate of change 0.16 . Built-up is of an increase with a change in $3653 \mathrm{Ha}$, a percentage change of $32.91 \%$ with annual rate of change of 4.94. However, within fifteen years (15) used as study periods positives changes in land use / land cover development were witnessed in commercial, residential and in industrial land use; while in industrial land use there were fluctuating and negative trends in both freshwater wetland and public areas.

The information on the land cover change from 1999-2003 based on Table 3 indicate that urban development in the metropolis experienced an increase in the built-up area by $1161.8 \mathrm{Ha}$ and $7.88 \%$ with annual rate of change 0.32 . This translated to fallow land with $388.8 \mathrm{Ha}, 7.78 \%$ and annual rate of change 0.31 respectively. Saltwater wetland is increased and untapped due to narrows gorges and canals for inflow of water into a larger water bodies. The freshwater wetland experienced sharp reduction with water bodies, freshwater wetland stands with negative reduction by $-1919.29 \mathrm{Ha},-14.89 \%$ with an annual rate of change of -0.6 , while water bodies experience a decline with $28.34 \mathrm{Ha}, 1.25 \%$ and annual rate of change of 0.05 .

From the change analysis of land use land cover from on Table 3 result shown that from 2003-2013 it was observed that there was an increase in built-up area by $3428.0 \mathrm{Ha}, 21.54 \%, 2.15$ of annual rate of change. These changes were due to increase in urban sprawls, migration activities, population growth and oil company activities. Most of the wetland are sold cleared for housing and infrastructural development. It is worthy to note that the metropolis grew uncontrolled within this period which transform to the creation of Greater Port Harcourt City. The implication of this change will definitely have adverse impact on the urban environment and proper urban management strategies are necessary to mitigate these effects. Water bodies have the positive change by $845.37 \mathrm{Ha}, 37.30 \%$ and 3.73 . These sudden increase in the volume of water bodies resulted in drainage capability and clearing of water ways and canals. Even seasonal flooding experienced in the metropolis can be attributed to such increase. The result above also indicate that from 2003-2013, other land use classes such as saltwater wetland/freshwater wetland and fallow land experienced a negative change in reduction. What is most evident in the results is that saltwater wetland made the lowest conversion by $-118.8 \mathrm{Ha},-2.15 \%$ and -0.22 annual rate of change. Freshwater wetland hit $-1219.63 \mathrm{Ha},-110.51 \%$ and an annual rate of change to -11.05 . The implication is that wetlands in the study area are threatened mainly by human and natural factors. Consequently, fallow land reduced considerably by $-195.07 \mathrm{Ha},-3.62 \%$ with annual rate of change to -47.13 in the metropolis.

The total percentage change and total rate of change for the whole trend is given below:

$\begin{array}{llll}\text { Saltwater Wetland } & -23.44 \% & \text { to } & -2.17 \\ \text { Freshwater Wetland } & -126.44 \% & \text { to } & -11.49 \\ \text { Fallow land } & -47.13 \% & \text { to } & -5.41 \\ \text { Built-up Area } & 43.33 \% & \text { to } & 7.41 \\ \text { Water bodies } & 43.36 \% & \text { to } & 3.06\end{array}$


Table 3. Magnitude, trend and percentage of change in land use/land cover from 1984-2013 in the study Area

\begin{tabular}{|c|c|c|c|c|c|c|c|c|c|c|c|c|c|c|c|c|c|c|}
\hline $\begin{array}{l}\text { LANDUSE/ } \\
\text { COVER } \\
\text { CATEGORIES }\end{array}$ & $\begin{array}{l}1984 \\
(\mathrm{Ha})\end{array}$ & $\begin{array}{l}1999 \\
(\mathrm{Ha})\end{array}$ & $\begin{array}{l}\text { CHA } \\
\text { NGE } \\
(\mathrm{Ha})\end{array}$ & $\begin{array}{l}\% \\
\text { CHA } \\
\text { NGE }\end{array}$ & $\begin{array}{l}\text { ANN } \\
\text { UAL } \\
\text { RAT } \\
\text { E OF } \\
\text { CHA } \\
\text { NGE }\end{array}$ & $\begin{array}{l}1999 \\
(\mathrm{Ha})\end{array}$ & $\begin{array}{l}2003 \\
(\mathrm{Ha})\end{array}$ & $\begin{array}{l}\text { CHA } \\
\text { NGE } \\
\text { (Ha) }\end{array}$ & $\begin{array}{l}\% \\
\text { CHA } \\
\text { NGE }\end{array}$ & $\begin{array}{l}\text { ANN } \\
\text { UAL } \\
\text { RAT } \\
\text { E OF } \\
\text { CHA } \\
\text { NGE }\end{array}$ & $\begin{array}{l}2003 \\
\text { (Ha) }\end{array}$ & $\begin{array}{l}201 \\
3\end{array}$ & $\begin{array}{l}\text { CHA } \\
\text { NGE }\end{array}$ & $\begin{array}{l}\% \\
\text { CHA } \\
\text { NGE }\end{array}$ & $\begin{array}{l}\text { ANN } \\
\text { UAL } \\
\text { RAT } \\
\text { E OF } \\
\text { CHA } \\
\text { NGE }\end{array}$ & $\begin{array}{l}\text { TOT } \\
\text { AL } \\
\text { CHA } \\
\text { NGE }\end{array}$ & $\begin{array}{l}\text { TOT } \\
\text { AL \% } \\
\text { CHA } \\
\text { NGE }\end{array}$ & $\begin{array}{l}\text { TOT } \\
\text { AL } \\
\text { RAT } \\
\text { E OF } \\
\text { CHA } \\
\text { NGE }\end{array}$ \\
\hline SALTWATER & 6086 & 5190. & -896 & -14.7 & -2.21 & 5190. & 5530. & 340.3 & 6.56 & 0.26 & 5530. & 541 & -118 & -2.15 & -0.22 & -1355 & -23.44 & -2.17 \\
\hline WETLAND & 52 & 23 & 29 & 3 & & 23 & 59 & 6 & & & 59 & 1.79 & 8 & & & .43 & & \\
\hline FRESHWATE & 1275 & 1288 & 135.6 & 1.06 & 0.16 & 1288 & 1096 & -1919 & -14.8 & -0.60 & 109.6 & 974 & -1219 & -110 & -11.0 & -3274 & -126.4 & -11.4 \\
\hline R WETLAND & 0.58 & 6.20 & 2 & & & 6.20 & 6.91 & .29 & 9 & & 6.91 & 7.28 & .63 & 51 & 5 & .54 & 4 & 9 \\
\hline FALLOW & 7777. & 4998. & -2779 & -35.7 & -5.36 & 4998. & 5387. & 388.8 & 7.78 & 0.31 & 5387. & 519 & -195 & -3.62 & -0.36 & -3363 & -47.13 & -5.41 \\
\hline LAND & 80 & 46 & .34 & 3 & & 46 & 26 & & & & 26 & 2.19 & 07 & & & .21 & & \\
\hline BUILT-UP & 1110 & 1475 & 3653. & 32.91 & 4.94 & 1475 & 1591 & 1161. & 7.88 & 0.32 & 1591 & 193 & 3428. & 21.54 & 2.15 & 8242. & 43.33 & 7.41 \\
\hline AREA & 0.80 & 3.80 & 0 & & & 3.80 & 5.6 & 8 & & & 5.6 & 43.6 & 0 & & & 8 & & \\
\hline WATER & 2350 & 2237. & -112 & -4.81 & -0.72 & 2237. & 2266. & 28.34 & 1.25 & 0.05 & 2266. & 311 & 845.3 & 37.30 & 3.73 & -986. & 43.36 & 3.06 \\
\hline BODIES & 89 & 9 & 99 & & & 9 & 24 & & & & 24 & 1.61 & 7 & & & 7 & & \\
\hline
\end{tabular}

Source: Author's Computations, 2015.

\subsection{Nature and Location of Changes in Land Use /Land Cover Class}

The essential facet of change detection, which controls what is actually changing to what: i.e. which land use class is changing to what? These information will reveal both the desirable and undesirable change and classes that are comparatively steady overtime. This valuable information will serve as a vital instrument in decision making, and the process also involves a pixel to pixel comparison of the study year raster image maps (Zubair, 2006). In terms of location of change, the emphases were based on wetlands and built-up area. Figure 9-16 show this change from 1984, 1999, 2003 and 2013. The result of the analysis and discussion are as thus.

It has been perceived that growth exists around clusters of infrastructural development, road network away from the settlement centers following an urban growth thereby of central place theory hypothesized by Christaller (1933). Although the pattern seems to be uniform across all the encroached sites in the study area, a built-up area is mainly located as an exposed bare soil away from fallow land.

Saltwater and freshwater wetlands are primarily situated in the South-East, South-West and North-East and North-West as seen from the image map. It was thinly dispersed around the urban fringed areas. Water bodies remain comparatively steady in this class between 1984, 1999, 2003, and 2013 as obvious in the percentage increase in Table 3. Fallow land covers mainly around Northern part of the metropolis with very small patches centered on South, South-East and South-West in that order.

\section{Conclusion and Recomendations}

This present study used remote sensing image data to analyze land use and land cover changes in the wetlands ecosystem of Port - Harcourt metropolis. The study also found that land use and land cover occurred within the Port-Harcourt wetlands ecosystem over a successive period of (1984-2013). Built-up area in the metropolis increased tremendously, infrastructural development was very high with a decreasing trend in freshwater wetlands, saltwater wetlands and fallow land. The explanations for changes in land use and land cover in the Port Harcourt metropolis are mostly socioeconomic stresses which comprise: quest for white collar-job, rate of immigration, population explosion, oil exploration and exploitation of natural resources, urban growth and industrialization. Therefore, if the rate of deterioration of wetlands ecosystem remains uncontrolled, in the nearest future, the benefit, value and services that we derived from wetland ecosystem will be extinct by our changing systems. Land use and land cover change is a problematic task to accomplish correctly. The land use and land cover changes shown in this study may not offer the vital clarifications for all problems associated to land use / land cover changes, but will help as a foundation to comprehend the patterns and likely consequences of land use/land cover changes in the metropolis.

Following the results of the study, the following are recommended:

(i) There shall be an improvement on the pattern of developments in the metropolis. 
(ii) Activities shrinking wetlands size should be thoroughly put to check by the government and better efforts should be focused on those activities that inspire wetland conservation.

(iii) There is need for implementation of wise use concept in Ramsar Strategic Planning and Sustainable Development Goals (SDGs) agenda in other to achieve our targeted goals on wetlands ecosystem wellbeing which Nigeria is a signatory to the treaty.

\section{References}

Abbas, I. I. (2008). Use of satellite Remote Sensing and Geographic Information Systems to monitor Land Degradation along Ondo Coastal Zone (Nigeria). Balwois, Orid Macedonia, 27, 1-13.

Akpoghomeh, O. S (2001). Street Map of Port Harcourt Metropolis and its environs. Kraft's Books Ltd. University of Ibadan. Ibadan.

Alagoa, E. J., \& Derefaka, A. A. (2002). The land and people of Rivers State: Eastern Niger Delta. Onyoma Research Publication.

Anderson, J. R., Hardy, E. E., Roach, J. T., \& Witmer, R. E. (2001). A Land use and Land Cover Classification System for Use with Remote Sensor Data. Geological Survey Professional Paper 964. A revision of the land use classification system as presented in U.S.

Chiadikobi, K. C., Omoboriowo, A. O., Chiaghanam, O. I., Opatola, A. O., \& Oyebanj, O. (2011). Flood risk assessment of Port Harcourt, Rivers State, Nigeria. Pelagia Research, 2(6), 287-298.

Christaller, W. (1933). Central place theory - Wikipedia free encyclopedia.

De Roeck, E. R., Verhoest, N. E. C., Miva, M. H., Lievens, H., Batelaan, O., Eludoyin, O. S., \& Akinola, O. (2015). Spatio - temporal analysis of wetland change in Port - Harcourt metropolis. Tanzania journal of Science, 41, 48-63.

Finlayson, C. M. (2012). Forty years of wetland conservation and wise use. Aquat Conserv Mar Freshwat Ecosyst, 22, 139-43.

Finlayson, C. M., Davidson, N., Pritchard, D., Milton, G. R., \& Mackay, H. (2011). The Ramsar Convention and ecosystem-based approaches to the wise use and sustainable development of wetlands. Journal of International Wildlife Law and Policy, 14, 176-198.

Fonji, S. F., \& Taff, G. N. (2014). Using satellite data to monitor land use and land cover change in North Eastern Latvia. Springer plus, 3, 61.

Gardner, R. C., \& Davidson, N. C. (2011). The Ramsar Convention. In B. A. Le Page (Ed.), Wetlands: Integrating Multidisciplinary Concepts (pp. 189-203). Springer: Dordrecht.

Inyang, P. B. E. (1975). Climate in In G. E. K. Ofomata (Ed.), In Nigeria in Maps, Eastern State (pp. 25-26). Ethiope Publish House, Benin City.

Izeogu, C. V., \& Aisuebeogun, A. (1989). Relief and Drainage. In E. J. Alagoa, \& T. N. Tamuno (Eds.), Land and People of Rivers State (pp. 24-30). Riverside Communication, Port - Harcourt.

James, G. K., Adegoke, J. O., Saba, E., Nwilo, P. C., \& Akinyede, J. (2007). Satellite-Based Assessment of the extent and changes in the Mangrove Ecosystem of the Niger Delta. Journal of Marine Geodesy, 30, 249-226.

Lambin, E. E, Rounsevell, M. D. A., \& Geist, H. J. (2000). Are Agricultural land use models to predict changes in land use intensity? Agriculture, Ecosystems and Environment, 82(1-3), 321-331.

Li, J., \& Chen, W. (2005). A Rule- based method for mapping Canada's Wetland Using Optical, Radar and DEM Data. International Journal of Remote Sensing, 26(22), 5051- 5069.

Liu, J., \& Ashton, P. S. (1998). FORMOSAIC: An individual based spatially explicit model for simulating forest dynamics in landscapes mosaics. Ecological Modeling, 106, 177-2000.

Mccarthy, M, Finlayson, M., Sanjivde, S., Pyiyanie, A., \& Vladimir, S. (2015). Sustainable development and ecosystem services. Brief for GSDR, 2015.

Mmom, P. C., Florence, W., \& Fred-Nwagwu, F. W. (2013). Analysis of Land use and Land cover Change around the City of Port Harcourt, Nigeria. Global Advanced Research Journal of Geography and Regional Planning, 2(5), 076-086. 
NEALE, C.M. U; WENGER, D., JAYANTHI, H., and FARAG, F. (2007). "Mapping and Monitoring Wetlands Using Airborne multispectral imagery". In Owe M and Neale C (eds), proceedings of symposium on Remote sensing for environmental Change Detection. International Association of hydrological Science Sciences (IAHS) Publication, 316: 100-109.

Ogionwo, O. (1979). A social survey of Port-Harcourt (pp. 47-48). Heinemann, Ibadan.

Okoye, T. O. (1975). Port-Harcourt. In G. E. K. Ofomata (Ed.), Nigeria in maps: Eastern States (pp. 92-93).. Ethiope, Benin City.

Oludare, H., Adedeja, O. O., Tope, A., \& Olukemi, L. A. (2015). Assessing and predicting changes in the status of Gambari forest reserve, Nigeria using remote sensing and GIS techniques. Journal of Geographic Information System, 7, 301-318.

Oyegun. C. U., \& Adeyemo, A. (1999). Port-Harcourt Region (pp. 1-12). Paragraphics Port Harcourt.

Taiwo, O. J., \& Areola, O. (2009). A Spatial Temporal Analysis of Wetland Losses in the Lagos Coastal Region, South Western Nigeria, Using Multi-Data Satellite Imagery. Paper presented at/GARSS Annual Conference, Cape Town, South Africa, September. 2009.

Thomas, A., \& Brendonck, L. (2008). Remote sensing and wetland Ecology: "A South African Case study". Sensors, 8, 3542-3556.

Tijani, M. N., Olaleye, A. O., \& Olubanjo, O. O. (2011). Impact of Urbanization on Wetland Degradation: A case study of Eleyele Wetland, Ibadan, South West, Nigeria. Proceeding of the Environmental Management Conference, Federal University of Agriculture, Abeokuta, Nigeria, 2011.

Trimble, S. W., \& Crosson, P. (2000). Land use: U.S. Soil Erosion rates: Myth and Reality. Science, 289, 5477

Umeuduji, J. E., \& Aiseuebeogun, A. (1999). Relief and Drainage. In C. U. Oyegun, \& A. Adeyemo (Eds.), Land and People of Rivers State (pp. 24-30). River side Communication, Port-Harcourt.

Veldkamp, A., \& Verburg, P. H. (2004). Modelling land use and environmental impact. Journal of Environmental Management, 7(2), 1-3.

Vitousek, P. M. H. A, Mooney, J., \& Melillo, L. (1997). Human domination of earth's ecosystems. Science, 277, 494-499.

Wali, E., Phil-Eze, P. O., \& Nwankwoala, H. O. (2018a). Saltwater- Freshwater wetland ecosystem and urban land use change in Port Harcourt metropolis, Nigeria. Earth Sciences Malaysia, 2(1), 01-07.

Wali E., Phil-Eze P. O., Nwankwoala, H. O. (2018b). Forecasting the future pattern of land use and land cover change in the wetland ecosystem of the Port Harcourt metropolis. International Journal of Emerging Engineering Research and Technology, 6(2), 1-7.

Wali, E., Nwankwoala, H. O., Ocheje, J. F., \& Chinedu, J. O. (2019a). Oil Spill Incidents and Wetlands Loss in Niger Delta: Implication for Sustainable Development Goals. International Journal of Environment and Pollution Research, 7(1), 1-20.

Wali, E. (2015). Urbanization and loss of wetland in Port-Harcourt metropolis, Nigeria (Unpublished Master's Thesis) University of Nigeria, Nsukka, Enugu State. Unn institutional repository.

World Wetlands Day. (2015). Wetlands and Sustainable Development. Wetlands for Our Future: 2015, Time for Global Action for People and Planet.

Zubair, A. O. (2006). Change Detection in Land use and Land cover Using Remote Sensing data and GIS: A Case Study of IIorin and its Environs in Kwara State (Unpublished Master's Thesis) University of Ibadan, Ibadan.

\section{Copyrights}

Copyright for this article is retained by the author(s), with first publication rights granted to the journal.

This is an open-access article distributed under the terms and conditions of the Creative Commons Attribution license (http://creativecommons.org/licenses/by/4.0/). 